\title{
Bone Mineral Density Measurement in Newly Diagnosed Primary Hyperparathyroidism Patients
}

\author{
Bahar TEKİN ${ }^{1}$, F. Buket BAYRAM ${ }^{1}$, Meliha Melin Uygur $^{2}$, Dilek GOGAS YAVUZ ${ }^{2}$
}

${ }^{1}$ Department of Internal Medicine, Marmara University Hospital, Marmara University School of Medicine, İstanbul, Turkey

2Department of Internal Medicine, Section of Endocrinology and Metabolism, Marmara University Hospital, Marmara University School of Medicine, İstanbul, Turkey

Methods: 256 PHPT patients with a mean age of 50,7 \pm 14
years (F/M:205/51) and 89 healthy controls with a mean
age of 38,8 \pm 10 years (F/M:67/22) were included in the
current study. Serum calcium, phosphorus,
parathormone (PTH), $25(\mathrm{OH})$ vitamin D, creatinine,
thyroid stimulating hormone (TSH), 24-hour urinary
calcium, bone mineral density (BMD), body mass
index(BMI) and systolic/diastolic blood pressures were
measured in both groups. Graphed instat was used for
statistical analysis.

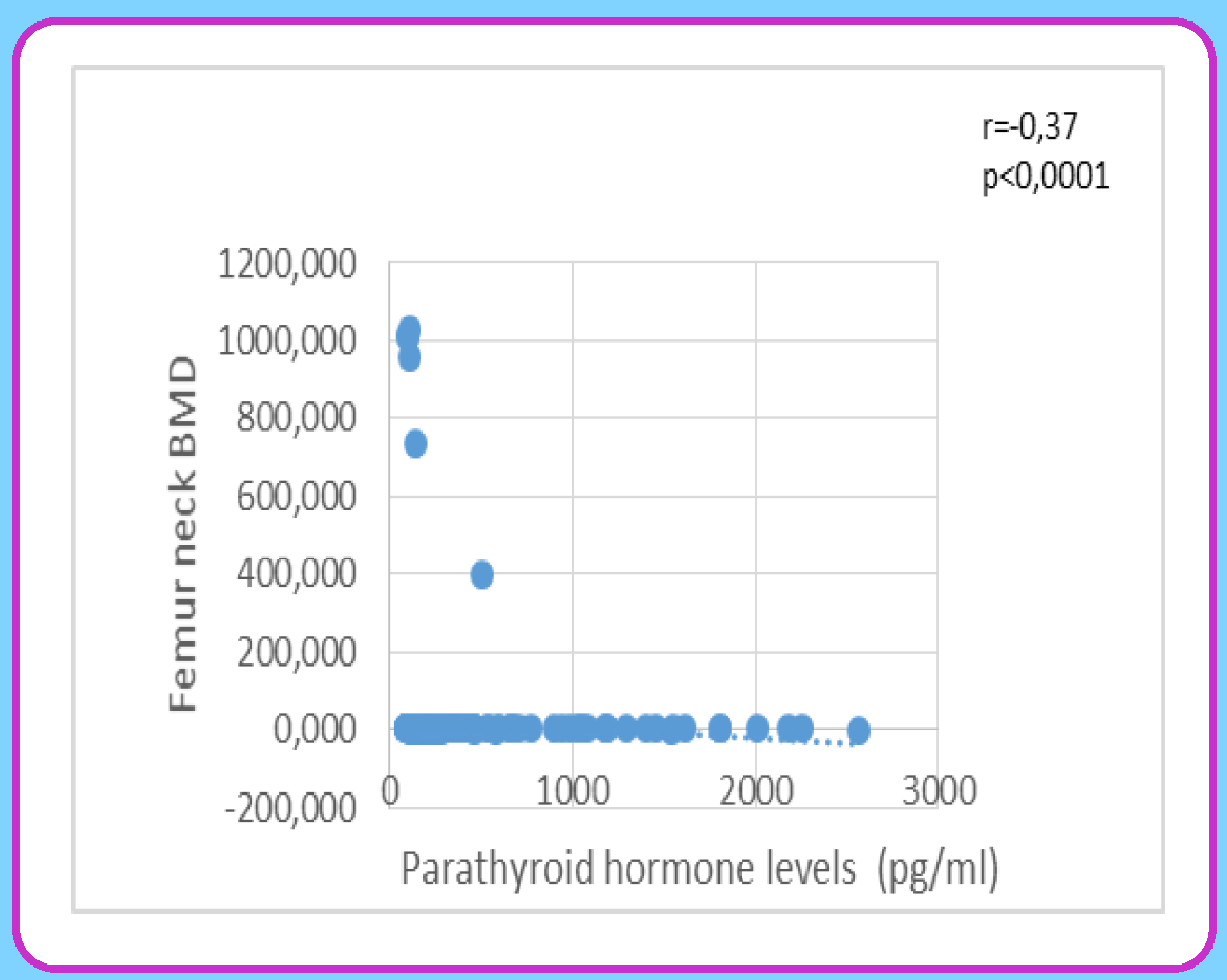

Results: \%20 of PHPT patients were symptomatic and nephrolithiasis was shown in $\% 20,3$ of the patients. Serum

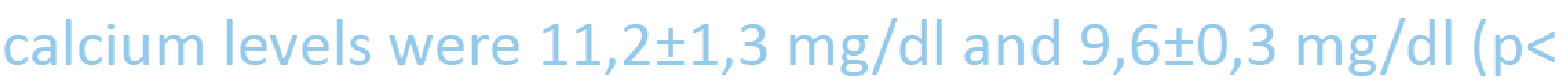
$0.0001)$, serum PTH levels were $273,4 \pm 374 \mathrm{pg} / \mathrm{ml}$ and $61,3 \pm 28 \mathrm{pg} / \mathrm{ml}(\mathrm{p}<0.001)$ and serum $250 \mathrm{H}$ D levels were $21,9 \pm 20,1 \mathrm{ng} / \mathrm{ml}$ and 10,4 \pm ,1 $\mathrm{ng} / \mathrm{ml}(\mathrm{p}<0,0001)$ for PHPT and control groups respectively. 24-hour urinary calcium

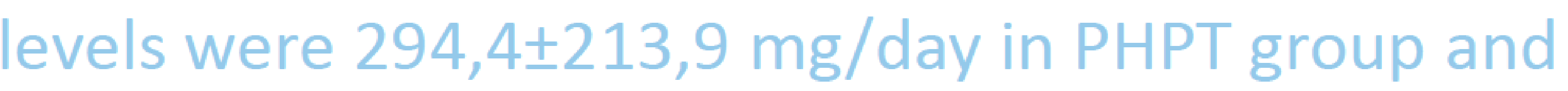
$137 \pm 69,2 \mathrm{mg} /$ day in healthy control group

$(p<0,0001)$.Femur neck BMD were 0,82 $\pm 0,15 \mathrm{~g} / \mathrm{cm} 2$ and $0,98 \pm 0,14 \mathrm{~g} / \mathrm{cm} 2(\mathrm{P}<0,0001)$ for PHPT and control groups respectively. Femur neck and lumber BMDs, T and Z scores were observed significantly lower in PHPT group compared to healthy controls group $(p<0.0001)$. Femur neck and lumber BMD levels showed negative correlation with PTH in PHPT patients ( $r=-0.37, p<0,0001)$. There were osteoporosis in 13.4 percent (n:34) and osteopenı in 9,9 percent (n:25) of PHPT patients.

\begin{tabular}{|c|c|c|c|}
\hline & $\begin{array}{c}\text { Primary } \\
\text { Hyperparathyroidi } \\
\text { n:256 }\end{array}$ & $\begin{array}{c}\text { Control } \\
n: 89\end{array}$ & $\mathbf{p}$ \\
\hline VKI (BMI) & $28,6 \pm 26,9$ & $29,9 \pm 6,6$ & 0,22 \\
\hline $\begin{array}{l}\text { Systolic Blood Pressure } \\
(\mathrm{mm} / \mathrm{hg})\end{array}$ & $128,9 \pm 16$ & $115,1 \pm 16,6$ & 0,0001 \\
\hline $\begin{array}{l}\text { Diastolic Blood Pressure } \\
(\mathrm{mm} / \mathrm{hg})\end{array}$ & $79,3 \pm 8,9$ & $70 \pm 13,5$ & 0,0001 \\
\hline Calcium (mg/dl) & $11,2 \pm 6,8$ & $9,6 \pm 0,39$ & 0,0001 \\
\hline Phosphorus (mg/dl) & $2,8 \pm 0,97$ & $3,15 \pm 0,48$ & 0,0001 \\
\hline $\begin{array}{l}\text { Parathyroid Hormone } \\
(\mathrm{pg} / \mathrm{ml})\end{array}$ & $273,4 \pm 347,4$ & $61,3 \pm 28,1$ & 0,0001 \\
\hline $25(\mathrm{OH}) \mathrm{D}(\mathrm{ng} / \mathrm{ml})$ & $21,9 \pm 21,2$ & $10,4 \pm 7,1$ & 0,0001 \\
\hline $\begin{array}{l}24 \text { Hours Urinary Calcium } \\
\text { (mg/gün) }\end{array}$ & $294,4 \pm 213,9$ & $137 \pm 69,2$ & 0,0001 \\
\hline Femur Neck BMD & $0,828 \pm 0,152$ & $0,985 \pm 0,147$ & 0,0001 \\
\hline
\end{tabular}

Conclusion: In our group of patients osteoporosis was diagnosed lower than expected but BMD measurements were lower in PHPT group. The results of this study show that bone turnover is increased and bone mineral density is decreased in PHPT patients, as stated in previous studies. 